\title{
FACTORS RELATED TO CARPAL TUNNEL SYNDROME (CTS) COMPLAINTS ON EMPLOYEES IN THE BANK BNI BRANCH OF PALU
}

\author{
Abdul Hamid ${ }^{1}$, Zikri Fathur Rahman' ${ }^{2}$, Sri Widati $^{1}$, Suherdin $^{3}$, Y. Denny Ardyanto ${ }^{1}$ \\ ${ }^{1}$ Department of Occupational Health and Safety, Faculty of Public Health Universitas Airlangga. \\ ${ }^{2}$ Polytechnic of health dr. Soepraoen \\ ${ }^{3}$ Faculty of Health Sciences, Bhakti Kencana University
}

\begin{abstract}
Carpal Tunnel Syndrome (CTS) is a disorder or disease that most often occurs in various industrial sectors. The National Health Interview Study (NHIS) estimates that the reported prevalence of CTS among the adult population is $1.55 \%$ (2.6 million). This research was conducted at BNI Branch Bank Palu. The research objective is to determine the factors associated with complaints of CTS on employees at BNI Branch Bank Palu. The type of research used is quantitative, using a cross-sectional approach. The number of samples was 109 people. Data were analyzed using the chi-square test at the level of confidence $(\rho<0.05)$. The results showed that there was a relationship between years of service $(\rho=0.005)$, length of work $(\rho=0,000)$, repetitive movements $(\rho=0.001)$ and gender $(\rho=0.006)$ with complaints of CTS on employees at the Bank BNI Palu Branch. It is recommended to employees of Bank BNI Branch Palu to do muscle stretches such as moving the fingers, reducing the emphasis on the carpal tunnel, to avoid the danger of disturbances originating from repetitive and monotonous movements in the long term.
\end{abstract}

Keywords: Work period, length of work, repetitive movement, gender, CTS

\begin{abstract}
ABSTRAK
Carpal Tunnel Syndrome (CTS) merupakan suatu gangguan atau penyakit yang paling sering terjadi diberbagai sector industry. National Health Interview Study (NHIS) memperkirakan bahwa prevalensi CTS yang dilaporkan diantara populasi dewasa adalah sebesar 1,55\% (2,6 juta). Penelitian ini dilaksanakan di Bank BNI Cabang Palu. Tujuan penelitian yaitu untuk mengetahui faktor-faktor yang berhubungan dengan keluhan CTS pada karyawan di Bank BNI Cabang Palu. Jenis penelitian yang digunakan yaitu kuantitatif dengan menggunakan pendekatan cross sectional. Jumlah sampel sebanyak 109 orang. Data dianalisis menggunakan uji chi square, pada taraf kepercayaan $(\rho<0,05)$. Hasil penelitian menunjukkan bahwa ada hubungan antara masa kerja $(\rho=0,005)$, lama kerja $(\rho=0,000)$, gerakan repetitif $(\rho=0,001)$ dan jenis kelamin $(\rho=0,006)$ dengan keluhan CTS pada karyawan di Bank BNI Cabang Palu. Disarankan kepada karyawan Bank BNI Cabang Palu untuk melakukan peregangan otot seperti menggerakkan jari-jari tangan, mengurangi penekanan pada terowongan carpal, agar terhindar dari bahaya gangguan yang bersumber dari gerakan berulang dan monoton dalam jangka waktu yang lama.
\end{abstract}

Kata Kunci: Masa kerja, lama kerja, gerakan repetitif, jenis kelamin,CTS

Correspondece Address: Y. Denny Ardyanto Department of Occupational Health and Safety, Faculty of Public Health Universitas Airlangga Email: denny.ard@gmail.com,dennyardyanto63@yahoo.co.id 


\section{INTRODUCTION}

Occupational safety and health (OHS) is a business plan whose application is useful to prevent the possibility of workplace accidents and diseases caused by work and the work environment. Occupational safety and health have objectives to be achieved, namely, to increase productivity, increase work efficiency, and reduce health costs. Employees who have a high level of physical, mental, and social health will be able to work with optimal mobilization so that high performance can be achieved and then can increase productivity. ${ }^{1}$

OHS in Indonesia is regulated in Law No. 1 of 1970, Regulation of the Minister of Manpower Number: Per 05 / MEN / 1996 December 12, 1996, and Indonesian Presidential Decree No. 22 of 1993 concerning diseases arising from work relations, including CTS. CTS arises due to nerves; the median is compressed in the carpal tunnel in the wrist, during the nerve pass through the tunnel from the forearm to the hand. CTS is one of the disorders reported by labor statistics agencies in developed countries as a disorder that is often found among industrial workers. ${ }^{2}$

Various activities that use many hands for a long time are often associated with the occurrence of CTS. CTS is related to work that uses a combination of strength and repetition of great movements of the fingers over a long period. CTS can be triggered due to exposure to movement or vibration or due to position errors that occur for long periods, for example, computer workers. The development of science and technology has made use of computer devices so that computers are now an essential requirement in expediting work in the work environment. Many benefits are obtained from the use of computers. Still, not many people realize that computer users can also cause problems, especially in a long time and continuously and with an incorrect position, one of which is the negative impact on health arising from the use of computers that is a complaint CTS. ${ }^{3}$

CTS is the center of attention of researchers because it can cause disability in employees, cause pain, and limit the function of wrist and hand movements so that it affects the daily work. CTS is caused by accumulative trauma, which is when the hands are moved repeatedly for an extended period with an excessive amount of movement in the fingers and hands. That causes the muscles or ligaments to become inflamed as a result of muscle and ligament compression and the blocking of the carpal tunnel. Based on several CTS studies that have been conducted, awareness of the factors that cause CTS in the work environment appears. In 1994, the United States Bureau of Labor Statistics stated that the rate of CTS cases was 4.8 cases per 10,000 workers, with $13 \%$ of cases caused by repetitive movements in the use of an instrument, or the position of holding a device or machine. ${ }^{4}$ 
The National Health Interview Study (NHIS) estimates that the reported prevalence of CTS among the adult population is $1.55 \%$ (2.6 million). NHIS also notes that CTS is more common in women than men with an age range between 25-64 years, the highest prevalence in women> 55 years. CTS usually begin there at the age of 20-60 years. The proportion of CTS is more found in respondents who have an age range of 25-34 years (89.2\%). CTS affects women more than men, which is 3.6 times greater than men. Based on the ratio between women and men for CTS has a reasonably significant difference of 3-10: $1 .^{5}$

According to the Bureau of Labor Statistics (BLS) report, the majority of diagnoses obtained were CTS disorders. ${ }^{6}$ In Indonesia, the prevalence of CTS in work problems is not yet known because very few diagnoses of occupational diseases are reported. Research on high-risk occupations in the wrist and hand found CTS prevalence between $5.6 \%-14.8 \% .^{7}$

Activities carried out with high frequency such as repetitive movements can be a risk factor for the onset of CTS and risk factors for the occurrence of incidents CTS include age, local vibrations, hand movements with strength, repetitive movements, and wrong working attitudes. Records of the Bureau of Labor Statistics (BLS), showed that of all reported cases, half were diagnosed as CTS. The results of the study involving 72 people from the informal sector showed that incidence CTS among jasmine picker workers in Karangcengis Village, Purbalingga, was $47.2 \%$ and suffered by 34 jasmine pickers, and showed the results that there was a relationship between frequency repetitive movements with the occurrence of CTS. The work of tea pickers at high risk of the occurrence of CTS with a frequency of $93.18 \%$ is to make repeated hand movements. ${ }^{8}$

Based on research Pratiwi it is known that 35 workers (83.3\%) with a work period of $>8$ years who experience abnormalities in muscles and nerves as many as 14 workers (35.9\%) with a working period of $<8$ years who experience muscle and nerve abnormalities. Workers who have years of service> 8 have 8,929 times the risk of experiencing CTS compared to workers who have $<8$ years of service. ${ }^{9}$ Because of degenerative changes in muscles, tendons, ligaments, or joints due to the aging process. More extended working periods for older workers and unbalanced physical load and physical capacity when compared with younger workers. ${ }^{10}$

Various activities that use many hands for a long time are often associated with the occurrence of CTS. CTS is related to work that uses a combination of strength and repetition of great movements of the fingers over a long period. Length of work is the length of time a worker works in one day. ${ }^{11}$ Based on research Elvi Dina, the proportion of CTS is more found in respondents who have 4 - 8 hours of work time (94.9\%), compared to respondents with great work $=4$ hours per day $(27.3 \%)$ who experience CTS. So it can be concluded that the length of work associated with the incidence of CTS. ${ }^{12}$ 
Based on a preliminary study conducted by researchers, the 15 employees at the BNI Bank Palu Branch interviewed consisted of 11 people (73.3\%) employees involved, including those outlining CTS. With complaints of aches and pains in the fingers as many as nine people (60\%), tingling in the fingers as many as 11 people (73.3\%) were numb and stiff in the fingers as many as eight people (53.3\%). Based on the above background, the researcher will raise the title of the research about the factors associated with CTS complaints on employees at BNI Branch Bank Palu. The research objective is to determine the factors associated with complaints of CTS on employees at BNI Branch Bank Palu.

\section{METHODS}

The research used is a quantitative research using a cross-sectional approach using observation techniques. The cross-sectional approach is the design of research that the data collection is done at a time or at one point in time. ${ }^{13}$ This research has been implemented in the Bank BNI Palu branch in September until October 2017.

The population in this research is employees at BNI Bank of Palu Branch, as the number of employees amounting to 109 employees. Samples are part of a population that is the object of a study. ${ }^{14}$ With the Total Sampling technique, the sampling techniques in which the number of samples is equal to the population. The instrument used in this study was to use a standardized questionnaire and was strengthened by making observations to strengthen the results of the study. Analysis of the data in this study using univariable and bivariable. The statistical analysis of the data was carried out using a Chi-Square test. This research has adjusted the applicable procedures and has been conducted an ethical test with 254 / HRECC.FODM / XI / 2017.

\section{RESULT}

\section{Univariate analysis of respondent characteristics at Bank BNI Branch of Palu}

Univariate analysis was carried out to see the distribution characteristics of respondent, such us age, education, gender, work period, repetitive movement, CTS at Bank BNI Branch of Palawan. The result of univariate analysis can be seen in table 1. 
Table 1. Univariate analysis of respondent characteristics at Bank BNI Branch of Palu

\begin{tabular}{|c|c|c|}
\hline Variabel & Frequency (f) & Percentage (\%) \\
\hline \multicolumn{3}{|l|}{ Age Group (Year) } \\
\hline $19-23$ & 1 & 0,9 \\
\hline $24-28$ & 26 & 23,9 \\
\hline $29-33$ & 60 & 55,0 \\
\hline $34-38$ & 14 & 12,8 \\
\hline $39-40$ & 8 & 7,3 \\
\hline \multicolumn{3}{|l|}{ Last Education } \\
\hline SMA & 9 & 8,3 \\
\hline S1 & 94 & 86,2 \\
\hline S2 & 6 & 5,5 \\
\hline \multicolumn{3}{|l|}{ Gender } \\
\hline Male & 51 & 46,8 \\
\hline Women & 58 & 53,2 \\
\hline \multicolumn{3}{|l|}{ Work Period } \\
\hline$\geq 4$ years & 97 & 89,0 \\
\hline$<4$ years & 12 & 11,0 \\
\hline \multicolumn{3}{|c|}{ Repetitive Movement } \\
\hline$>30 x$ in 1 minute & 106 & 97,2 \\
\hline$<30 \mathrm{x}$ in 1 minute & 3 & 2,8 \\
\hline \multicolumn{3}{|l|}{ CTS } \\
\hline Risk & 96 & 88,1 \\
\hline Not at risk & 13 & 11,9 \\
\hline
\end{tabular}

Gender Relationship with CTS complaints to Employees at Bank BNI Branch of Palu

The results of the bivariate analysis of sex relations with complaints of CTS to employees at Bank BNI Branch Palu can be seen in table 2.

Table 2. Relationship Sex with complaints CTS employee in Bank BNI Branch of Palu

\begin{tabular}{ccccccccc}
\hline \multirow{2}{*}{ Gender } & \multicolumn{4}{c}{ Complaint CTS } & \multicolumn{2}{c}{ Number } & \multirow{2}{*}{$\boldsymbol{\rho}$.value } & \multirow{2}{*}{$\begin{array}{c}\text { PR } \\
\text { CI 95\% }\end{array}$} \\
\cline { 2 - 6 } & \multicolumn{3}{c}{ Risk } & \multicolumn{2}{c}{ No-Risk } & & & \\
\cline { 2 - 6 } & $\mathrm{n}$ & $\%$ & $\mathrm{n}$ & $\%$ & $\mathrm{n}$ & $\%$ & & \\
\hline Male & 40 & 78.4 & 11 & 21.6 & 51 & 100 & \multirow{2}{*}{$(0,006)$} & 1,596 \\
Women & 56 & 96.6 & 2 & 3.4 & 58 & 100 & & $1.059-2.407$ \\
\hline
\end{tabular}

Data in table 1 shows that male respondents are more at risk of CTS as many as 40 people (78.4\%) while those with no CTS risk were 11 people (21.6\%) and those who were female were more at risk of CTS as many as 56 people (96.6\%) while those who are not at risk of CTS were two people $(3.4 \%)$.

Based on the results of the analysis using the Chi-Square test, the value of $\rho \leq \alpha(\rho=0,006)$ was obtained, so Ho in this study was rejected, meaning that there was a relationship between gender and CTS complaints on employees at BNI Branch Bank Palu. The prevalence value of workers' gender ratio $>1$, which means that workers with female gender 1,596 times the risk of experiencing CTS compared to workers with the male gender. 


\section{Relationships Work Period with complaints CTS employee in Bank BNI Branch of Palu} Result of bivariate analysis relationships tenure with complaints CTS employee in Bank BNI Cabang Palu can be seen in table 3

Table 3. Relationship Work Period with complaints CTS employee in Bank BNI Branch of Palu

\begin{tabular}{|c|c|c|c|c|c|c|c|c|}
\hline \multirow{3}{*}{ Time Occupational } & \multicolumn{4}{|c|}{ Complaints CTS } & \multirow{2}{*}{\multicolumn{2}{|c|}{ Amount }} & \multirow{3}{*}{$\rho . v a l u e$} & \multirow{3}{*}{$\begin{array}{c}\text { PR } \\
\text { CI } 95 \%\end{array}$} \\
\hline & \multicolumn{2}{|c|}{ Risk } & \multicolumn{2}{|c|}{ No risk } & & & & \\
\hline & $\mathrm{n}$ & $\%$ & $n$ & $\%$ & $\mathrm{n}$ & $\%$ & & \\
\hline$\geq 4$ years & 89 & 91.8 & 8 & 8.2 & 97 & 100 & \multirow{2}{*}{$(0,005)$} & \multirow{2}{*}{$\begin{array}{c}2,192 \\
1.445-3.325\end{array}$} \\
\hline$<4$ years & 7 & 58.3 & 5 & 41.7 & 12 & 100 & & \\
\hline
\end{tabular}

Data in table 3 shows that respondents with a work period of $\geq 4$ years are more at risk of CTS as many as 89 people (91.8\%) while those who are not at risk of CTS are as many as eight people $(8,2 \%)$ and respondents who worked for $<4$ years more at risk of CTS were seven people $(58.3 \%)$ while those who were not at risk of CTS were five people $(41.7 \%)$.

Based on the analysis using the Chi-Square test, it was found that the value of $\rho \leq \alpha$ $(\rho=0,005)$, so that Ho in this study was rejected, meaning that there is a relationship between work tenure and CTS complaints on employees at BNI Branch Bank Palu. The value of the prevalence ratio of tenure of workers $>1$, which means that workers with years of service $\geq$ four years at risk 2,192 times experience CTS compared to workers who have tenure of $<4$ years.

Relationship of Length of Work with Complaints of CTS in employees at Bank BNI Branch of Palu

Results of the bivariate analysis of the relationship of the length of work with complaints of CTS to employees at Bank BNI Branch Palu can be seen in table 4.

Table 4. Relationship of Length of Work with Complaints of CTS on employees at Bank BNI Branch Palu

\begin{tabular}{ccccccccc}
\hline \multirow{2}{*}{$\begin{array}{c}\text { Length of } \\
\text { Work }\end{array}$} & \multicolumn{4}{c}{ CTS complaints } & \multicolumn{2}{c}{ Amount } & \multirow{2}{*}{$\boldsymbol{\rho . v a l u e}$} & \multirow{2}{*}{$\begin{array}{c}\text { PR } \\
\text { CI 95\% }\end{array}$} \\
\cline { 2 - 6 } & \multicolumn{2}{c}{ Risk } & \multicolumn{2}{c}{ No risk } & & & \\
\hline & $\mathrm{n}$ & $\%$ & $\mathrm{n}$ & $\%$ & $\mathrm{n}$ & $\%$ & & 1,606 \\
\hline 4 hours & 95 & 93.1 & 7 & 6.9 & 102 & 100 & \multirow{2}{*}{0} & $1.101-2.341$ \\
\hline 4 hours & 1 & 14.3 & 6 & 85.7 & 7 & 100 & & \\
\hline
\end{tabular}

Data in table 4 shows that respondents who worked longer than jam4 hours were more at risk of CTS as many as 95 people (93.1\%) while those who were not at risk of CTS were seven people ( $6.9 \%)$ and respondents who worked $<4$ hours more were not at risk of CTS by six people (85.7\%) while those at risk of CTS were one person (14.3\%). 
Based on the analysis using the test Chi-Square, it was found that the value of $\rho \leq \alpha$ $(\rho=0,000)$, so Ho in this study was rejected, meaning that there is a relationship between the length of work and complaints of CTS on employees at BNI Bank Palu Branch. The value of the prevalence ratio of the length of work $>1$, which means that workers who have a work duration of $\geq 4$ years 1,606 times are at risk of experiencing CTS compared to workers who have a length of work $<4$ years.

\section{Repetitive motion relationship with CTS on Employee Complaints in Bank BNI Branch of Palu}

Result of bivariate analysis repetitive motion relationship with CTS complaint on employees in Bank BNI Cabang Palu can be seen in Table 5

Table 5. Repetitive Movement relationship with CTS complaint on employees in Bank BNI Branch of Palu

\begin{tabular}{|c|c|c|c|c|c|c|c|c|}
\hline \multirow{3}{*}{$\begin{array}{l}\text { Repetitive } \\
\text { Movement }\end{array}$} & \multicolumn{4}{|c|}{ CTS complaints } & \multirow{2}{*}{\multicolumn{2}{|c|}{ Amount }} & \multirow[t]{3}{*}{$\rho . v a l u e$} & \multirow{3}{*}{$\begin{array}{c}\text { PR } \\
\text { CI } 95 \%\end{array}$} \\
\hline & \multicolumn{2}{|c|}{ Risk } & \multicolumn{2}{|c|}{ No risk } & & & & \\
\hline & $\mathrm{n}$ & $\%$ & $\mathrm{n}$ & $\%$ & $\mathrm{n}$ & $\%$ & & \\
\hline$>30 \mathrm{x}$ in 1 minute & 96 & 90.6 & 10 & 9.4 & 106 & 100 & (0م01) & 1,815 \\
\hline$<30 \mathrm{x}$ in 1 minute & 0 & 0 & 3 & 100 & 3 & 100 & $(0.001)$ & $0,762-2,027$ \\
\hline
\end{tabular}

Data in table 5 shows that respondents who did repetitive movements> 30x in 1 minute had more risk of CTS as many as 96 people (90.6\%). In comparison, those who were not at risk of CTS were 103 people (9.4\%), and respondents who did repetitive movements <30x in 1 minute were not at risk of CTS as many as three people (100\%).

Based on the analysis using the test, the Chi-Square value of $\rho \leq \alpha(\rho=0,001)$ was obtained, so Ho in this study was rejected, meaning that there was a relationship between repetitive movements and complaints of CTS on employees at BNI Bank Palu Branch. The prevalence ratio value of workers' repetitive movements $>1$, which means workers with repetitive movements $>30$ times in 1 minute 1,815 times are at risk of experiencing CTS compared to workers with repetitive movements $<30$ times in 1 minute.

\section{DISCUSSION}

Presence of hormonal differences in women, especially during pregnancy dam menopause. During pregnancy is caused by fluid retention that often occurs during pregnancy, which puts additional pressure on the tunnel carpal and causes symptoms. However, some women experience no symptoms until after childbirth and early breastfeeding. Breastfeeding temporarily decreases the levels of hormones steroid natural, which increases the potential for inflammation and is also caused by anatomical differences in carpal bones where the wrist bones in women are naturally smaller to create tighter spaces, where nerves and tendons must be straight. While hormonal 
changes, menopausal can put women at higher risk of getting CTS because the structure of the wrist enlarges and can suppress the wrist nerves. ${ }^{15}$

Based on the results of the analysis, it shows that there is a relationship between gender and CTS complaints among employees at BNI Bank Palu Branch. This is because the size of the Carpal Sheet in women is smaller than in men. Most employees at the BNI hammer branch are women because women are more careful in their work and so on. The average muscle strength of women is only about $60 \%$ of the muscle strength of men, especially for the muscles of the arms, back, and legs. ${ }^{16}$

This research is in line with research conducted by Sisti Rohmah. In this study, the relationship of CTS with gender found that female workers suffered more CTS than male workers. This means that female workers have a risk of 3.5 times to experience CTS compared to male workers. ${ }^{17}$ This research is also in line with research conducted by Tana. In this study, most respondents were women $(95.6 \%)$, while men were only (4.4\%). The relationship between CTS and gender found that male workers suffered less CTS than female workers. ${ }^{18}$

This study is not in line with research conducted by Elvi Dina. In this study, of the 93 sex respondents, $51.6 \%$ were mostly male. Gender relationship with CTS is found in respondents with male genital enis by $29 \%$. There is no relationship between sex with the occurrence of CTS in this study, probably due to the work of male batik crafters with standing work attitude and pressure on the hands obtained from heavy batik tools riskier than the work of female batik artisans with approach sitting job and lighter batik tools. ${ }^{12}$ This research is also not in line with research conducted by Fitriani, this study shows that there is no relationship between sex and the incidence of CTS. However, there are differences with data from the National Health Interview Study (NIHS) which states the prevalence of CTS in the general population has been estimated at $5 \%$ for women and $0.6 \%$ for men. ${ }^{19}$

The working period is a period or the length of time a workforce works in a place. The range of service can affect performance, both positively and negatively. Gives a positive influence on performance when the more extended the personal work period, the more experienced in carrying out their duties. On the contrary, it will have a negative effect if, with the increasing length of service, the work habits will arise..$^{20}$

Based on the analysis found, there is a relationship between the length of work and complaints of CTS. CTS to employees at BNI Bank Palu Branch. This is because more respondents have a work period of 4 years, so respondents often use hand movements when working for long periods and repeatedly can disrupt the tissue around the wrist, which can trigger an inflammatory process that causes the tunnel channel to become narrow and compressed ${ }^{15}$. The median nerve and causes CTS complaints. According to Bambang Suherman, Degenerative changes in muscles, tendons, ligaments. Alternatively, joints due to the aging process, more extended work periods for 
older workers, and unbalanced physical burden and physical capacity when compared to younger workers. ${ }^{21}$

This research is in line with research by Nunik Nur Wulandari. In this study, the work period of chili picker workers is categorized into two categories, namely $>4$ years and $<4$ years. Based on this research, it is known that the risk of CTS incidents is experienced by many chili pickers who work for more than four years of work as many as 17 people (73.9\%). Test results Chi-Square between years of service and CTS events get $\rho=0,009$ shows that there is a significant relationship between a work period and CTS events. ${ }^{22}$ This study is also in line with the research conducted by Bambang Suherman, a person who worked for $>4$ years had a sizeable proportion (92.0\%) compared to the work period of 1-4 years (88.2\%) who experienced an incident positive CTS. This means that respondents with a work period of $>4$ years have a risk of experiencing CTS 18,096 times greater than workers whose work period is $1-4$ years. ${ }^{21}$

Long working hours will cause a decrease in the quality and results of work, and work with prolonged or long periods can cause a tendency to occur fatigue, health problems, illnesses and accidents, and dissatisfaction. ${ }^{23}$ Based on the analysis, it was found that there is a relationship between the length of work and Carpal complaints. CTS for employees at BNI Bank Palu Branch. This is because respondents work using a keyboard and mouse for 4 hours per day, which increases the risk of experiencing CTS complaints on the wrist. The longer a person works, the longer the stress on the nerves can increase the incidence of CTS. With the increase in the length of work, indicating the existence of repeated work done by hand in an extended period, indicating a higher risk for the occurrence of CTS. ${ }^{24}$

According to Wita Maharani, several epidemiological studies also concluded that the duration of maintaining a posture showed a relationship exposure-response with the incidence of CTS. If the risk factor for long periods of work, then the impact is decreased ability of the body and can cause pain in the limbs. ${ }^{25}$ This research is in line with a study conducted by Sekarsari \& Pratiwi, It is known that the results of Tedeschi square at a 95\% confidence level or a $=0.05$ obtained sig $(\rho=0,032)$ so that there is a relationship between the length of work with complaints CTS on stone-breaking workers in Moramo Utara District Konawe Regency South. ${ }^{26}$

Repeated movements with a frequency of $>30$ times a minute and performed every day can increase tendinitis, which causes nerve compression and cause CTS. So it is recommended to do rest and stretch in the hand so that it can accelerate blood flow in blood vessels. ${ }^{27}$ Based on the analysis, it was found that there is a relationship between repetitive movements and CTS complaints. To employees at BNI Bank Palu Branch. This happens because the higher the frequency of repetitive motions, the higher the risk of CTS so that the muscles receive pressure due to continuous workload without getting a chance for relaxation. ${ }^{15}$ 
Someone who works by doing repetitive movements on the hands and wrists is a repetitive work activity that involves movement of the fingers of the hand is a factor influencing CTS complaints that influences physical workload factors. ${ }^{28}$ The theory put forward by Robby Perdana Sakti, increasing repetition of the same movements every day, will increase the risk of tendinitis. This damage can cause nerve compression and cause CTS. Repeated movements will increase the pressure on the carpal tunnel. Emphasis on the carpal tube will cause damage to reversible or irreversible. Increased intensity and duration that is long enough will reduce blood flow in peripheral blood vessels. In the long-term, blood flow will affect the capillary circulation and ultimately have an impact on the permeability of the blood vessels in the wrist. ${ }^{29}$

At the time of carrying out their work activities, workers may have experienced pain disorders, but are simply ignored assuming it is a normal thing, and it is appropriate to happen with the existing workload. This study is also in line with research conducted by Pratiwi, on onion skin cleaning workers found that respondents with repetitive movements> 30 times per minute experience CTS 50.9\%. This proves that repetitive movements in a short time provide an excellent opportunity for the occurrence of CTS. ${ }^{9}$

This study is in line with research by Kurniawan that the result of analysis with the statistical test is chi-square known that there is a relationship between the frequency of repetitive movements with CTS $(\rho=0,013, \alpha=0,05)$. That is, a high frequency of repetitive movements $>30$ times movement per minute) in work will cause CTS. The higher the rate of repetitive motions, the higher the risk of CTS. ${ }^{30}$ This study is not in line with research conducted by Latifa Ekiyana Dewi, based on the results of the statistical test, it is chi-square known that there is no relationship between the recurring movement factors with CTS $(\rho=0,083, \alpha=0,05)$. This means that someone who has a history of CTS-causing illnesses such as wrist trauma and fractures does not always suffer from CTS. ${ }^{31}$ The same is evident from the results of this study are not consistent with research conducted Fagarasanu \& Kumar that there is no relationship between repetitive motion with complaints of CTS with test results of the statistical relationship repetitive motion with complaints of CTS show the value $(\rho=0,196, \alpha=0,05) .{ }^{32}$

\section{CONCLUSION}

Based on the results of the study and referring to the discussion that the author has explained in the previous section, it concludes: that CTS risk factors including, years of service, length of work, repetitive movements, and gender are associated with complaints of CTS to employees at BNI Bank Palu Branch. The findings in this study can be input into the management of Bank BNI Branch Palu to make efforts to prevent and control CTS including paying attention to the length of service, length of work, and sex of workers. It can also give workers time to stretch. 


\section{REFERENCE}

1. Setiawan IN. Pengaruh Keselamatan Dan Kesehatan Kerja Terhadap Produktivitas Karyawab Pada Departemen Jaringan PT PLN ( PERSERO ) Area Surabaya Utara Indra Novri Setiawan Jurusan Manajemen , Fakultas Ekonomi , Universitas Negeri Surabaya , Kampus Ketintang Surabaya 60. J Ilmu Manaj. 2013;1(2).

2. Syahrul LS dan. Carpal Tunel Syndrome. J Kedokt Syiah Kuala. 2014;14(1):29-37.

3. Novita Isman. Hubungan Masa Kerja dan Desain Tempat Kerja pada Pekerja Rental Komputer. 2015;1(5):7-12.

4. Ayu G, Juniari R, Triwahyudi A. Hubungan Antara Masa Kerja Terhadap Keluhan Carpal Tunnel Syndrome (CTS) Pada Pegawai Perempuan Di Kampus Universitas Dhyana Pura Yang Bekerja Mengunakan komputer. J Virgin. 2015;1(2):162-8.

5. Lazuardi AI, Ma I, Hartanti RI, Kalimantan J. Determinan Gejala Carpal Tunnel Syndrome ( CTS ) pada Pekerja Pemecah Batu ( Studi pada Pekerja Pemecah Batu di Kecamatan Sumbersari dan Sukowono Kabupaten Jember ). 2016;1(2):6-10.

6. Melati P, Kurniawan B, Jayanti S, Setyaningsih Y. Faktor Risiko Kejadian Carpal Tunnel Syndrome (CTS) pada Wanita Pemetik Melati di Desa Karangcengis, Purbalingga. Fakt Risiko Kejadian Carpal Tunn Syndr pada Wan Pemetik Melati di Desa Karangcengis, Purbalingga. 2008;3(1):31-7.

7. Nissa PC, Widjasena B, Masyarakat FK, Diponegoro U. Hubungan Gerakan Repetitif Dan Lama Kerja Dengan Keluhan Cerpal Tunnel Syndrome Pada Mahasiswa Teknik Arsitektur. J Kesehat Masy. 2015;3(April).

8. Selviyati V, Camelia A, Sunarsih E. Analisis Determinan Kejadian Carpal Tunnel Syndrome ( CTS ) Pada Petani Penyedap Pohon Ksret di Desa Karang Manik Kecematan Belitang II Kabupaten Oku Timur. J Ilmu Kesehat Masy. 2016;7(November):198-208.

9. Pratiwi. Faktor-faktor yang Mempengaruhi Kejadian Carpal Tunnel Syndrome (CTS) pada Pekerja Pembersih Kulit Bawang di Unit Dagang (UD) Bawang Lanang Kelurahan Iringmulyo Kota Metro. 2015;2(1):138-45.

10. Rahman ZF, Tualeka AR. Risk Assessment, Risk Management, and Risk Communication in the Carpet Industry: PT . ' X' Pandaan . East Jawa. Indian J Forensic Med Toxicol. 2020;12(January-March).

11. Rahman ZF. Pengaruh Masa Kerja Dengan Terjadinya Low Back Pain Pada Karyawan Di Unit Kerja Jahit Di Pabrik Karpet "X" Kec. Pandaan Kab. Pasuruan. University of Muhammadiyah Malang; 2017.

12. Elvi Dina. Faktor-faktor Yang Berhubungan Dengan Risiko Terjadinya Carpal Tunnel Syndrome Pada Perajin Batik Di Kelurahan Pasirsari Kota Pekalongan. 2016;2(1):1-16.

13. Swarjana i ketut. metode penelitian kesehatan. yogyakarta: cv andi offset; 2012.

14. Hermawanto H. menyiapkan karya tulis ilmiah. In: Panduan untuk Menyusun Karya Tulis Ilmiah di Bidang Kesehatan. jakarta: TIM; 2010.

15. Rahman ZF. Coal Dust and Acute Respiratory Infections in South Kalimantan PT ' X ' Coal Mining Workers.

16. Tarwaka. Ergonomi untuk keselamatan, kesehatan kerja dan produktivitas. Surakarta: Harapan Press; 2004.

17. Siti Rohmah. Analisis Hubungan Faktor-Faktor Individu Dengan Carpal Tunnel Syndrome (Cts) Pada Pekerja Konveksi. Ianaco. 2016;1:73-9.

18. Tana L. Peran Latihan Tangan Dalam Pencegahan Carpal Tunnel Syndrome Pada Perempuan Pekerja Garmen. J Ekol Kesehat. 2012;11(2):165-77.

19. Hafsari D, Ramadhian MR, Saftarina F. Debu Batu Bara Dan Kejadian Infeksi Saluran Pernafasan Akut Pada Pekerja Pertambangan Batu Bara. Majority. 2015;4(9):35-41.

20. Riska Riski. Hubungan Antara Masa Kerja dan Pemakaian Masker Sekali Pakai dengan Kapasitas Vital Paru pada Pekerja bagian Composting di PT. Zeta Agro Corporation Brebes. 2013;

21. Bambang Suherman SM dan YF. Beberapa Faktor Kerja Yang Berhubungan Dengan Kejadian Carpal Tunnel Sydrome (CTS) Pada Petugas Rental Komputer Di Kelurahan 
Kahuripah Kota Tasikmalaya. 2012;10(2):1-11.

22. Nunik Nur Wulandari. Hubungan Umur, Masa Kerja , IMT dan Frekuensi Gerakan Repetitif dengan Kejadian Carpal Tunnel Syndrome. 2016;36(3):1-11.

23. Dina Lusiana Setyowati, Dwijayanti D, Sultan M. Related Factors Of Carpal Tunnel Syndrome ( Cts ) Among Onion Skin Peeler Worker At Segiri. J Kesmas. 2015;9(2):125-32.

24. Rempel D, Evanoff B, Amadio PC, Krom M De, Franklin G, Franzblau A. Commentary Consensus Criteria for the Classification of Carpal Tunnel Syndrome in Epidemiologic Studies. Am J Public Health. 2017;88(10):1447-51.

25. Wita Maharani. Hubungan Karakteristik Individu dan Lama Kerja Dengan Kejadian Carpal Tunnel Syndrome (CTS) Pada Pekerja Bagian Pemotongan di PT. X Slamen, Yogyakarta. 2013;2:9-17.

26. Sekarsari D, Pratiwi AD. Hubungan lama kerja, gerakan repetitif dan postur janggal pada tangan dengan keluhan carpal tunnel syndrome (cts) pada pekerja pemecah batu di kecamatan moramo utara kabupaten konawe selatan tahun 2016. Jimkesma. 2017;2(6):1-9.

27. Hakim AL, Tjandra R. Hubungan Tingkat Keparahan Gejala Dan Status Fungsional Pada Pasien Carpal Tunnel Syndrome Diukur Menggunakan Carpal Tunnel Syndrome Assessment. J Kedokt diponegoro. 2016;5(3):174-87.

28. Winarti M, Basuki B, Hamid A. Air Movement, Gender and Risk of Sick Building Syndrome Headache Among Employees in a Jakarta Office. Med J Indones. 2003;12(3):171-7.

29. Robby Perdana Sakti. Hubungan Karakteristik Individu dan Kondisi Kerja dengan Kejadian Carpal Tunnel Syndrome (CTS) pada Oprator Komputer Warung Internet di Kelurahan Sumbersari Kabupaten Jember. J Kesehat. 2013;10(1):11-4.

30. Nandar S, Husna M, Al Rasyid H, Bilqis N. The Relationship Of Carpal Tunnel Syndrome Clinical Symptomps And Electroneuromyography Results in Rssa Malang. MNJ (Malang Neurol Journal). 2015 Jan 1;2:23-8.

31. Latifa Ekiyana Dewi. Pengaruh penambahan ultrasound pada latihan neural stretching terhadap peningkatan kemampuan fungsional wrist pada carpal tunnel syndrome. J Kesehat. 2017;53(4):1-15.

32. Fagarasanu M, Kumar S. Carpal tunnel syndrome due to keyboarding and mouse tasks: a review. Inter Natl J Ind Ergon. 2014;31(2):119-36. 